\title{
Sea level $\sim 400000$ years ago (MIS 11): analogue for present and future sea-level?
}

\author{
D. Q. Bowen \\ School of Earth and Ocean Sciences, Cardiff University, Cardiff, CF10 3YE, UK \\ Received: 29 April 2009 - Published in Clim. Past Discuss.: 13 July 2009 \\ Revised: 30 November 2009 - Accepted: 9 December 2009 - Published: 19 January 2010
}

\begin{abstract}
Comparison of the sea-level today with that of 400000 years ago (MIS 11), when the Earth's orbital characteristics were similar may provide, under conditions of natural variability, indications of future sea-level during the present interglacial. Then, as now, orbital eccentricity was low and precession dampened. Evidence for MIS 11 sealevel occurs on uplifting coastlines where shorelines with geochronological ages have been preserved. The sea-level term and the uplift term may be separated with an "uplift correction" formula. This discovers the original sea-level at which the now uplifted shoreline was fashioned. Estimates are based on average uplift rates of the "last interglacial" sealevel (MIS 5.5) using a range of estimates for sea-level and age at that time at different locations. These, with varying secular tectonic regimes in different ocean basins, provide a band of estimates for the MIS 11 sea-level. They do not support the hypothesis of an MIS 11 sea-level at $\sim 20 \mathrm{~m}$, and instead show that it was closer to its present level.
\end{abstract}

\section{Introduction}

Inferences about sea-level variability have been drawn from the oxygen isotope variability $\left(\delta^{18} \mathrm{O}\right)$ of marine foraminifera ever since Emiliani (1955) proposed correlations between $\delta^{18} \mathrm{O}$ and classical continental stratigraphy. This was extended by correlations between sea-levels, $\delta^{18} \mathrm{O}$ and solar variability (Fairbridge, 1961). Whereas Emiliani (1955) placed greater emphasis on the temperature term rather than the isotopic composition of the ocean in the partitioning of ${ }^{16} \mathrm{O}$ and ${ }^{18} \mathrm{O}\left(\delta^{18} \mathrm{O}\right)$, Shackleton (1967) argued that the $\delta^{18} \mathrm{O}$ signal from bottom water benthic foraminifera, where little

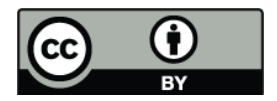

Correspondence to: D. Q. Bowen (bowendq@cardiff.ac.uk) if any temperature change occurred, is a signal of ocean isotopic variability. Because this is controlled by continental ice-volume, it is also a signal of sea-level variability. Shackleton and Opdyke (1973) proposed that $0.1 \%$ of $\delta^{18} \mathrm{O}$ change is equivalent to a $100 \mathrm{~m}$ of sea-level change: thus $0.01 \%$ o corresponds with $10 \mathrm{~m}$ of sea-level change. Subsequently, it was realised that ocean bottom water temperatures did change in the past and regional hydrological variability is also a factor in the partitioning of the oxygen isotope signal (e.g. Lea et al., 2002). Many clever attempts have been made to convert $\delta^{18} \mathrm{O}$ to its sea-level equivalent by Chappell (1974), Shackleton and Chappell (1986), Shackleton (1987), Waelbroeck et al. (2002), McManus et al. (2003), and Zeigler et al. (2003) believed that ocean core SITE 849 from the NE Pacific may provide a close approximation for sea-levels of the last $0.5 \mathrm{Ma}$ (Mix et al., 1995). More recently, correlations have been made between oxygen isotope, temperature and carbon dioxide variability in Antarctic ice cores with sealevel (Rohling et al., 2009). But all such correlations with sea-level are based on inference of one kind or another.

The only reliable indicators of former sea-levels (waterlevels) are geological actualities on the global shore and its immediate hinterland. Advances in geochronology beyond the range of radiocarbon dating have opened up possibilities to obtain ages for old shorelines. Most of these, however, have been uplifted above the present sea-level so that "uplift correction" is needed (see Sect. 2 below). Evidence for former sea-levels is provided by: marine terraces, shoreline angles, erosional and bioerosional notches, littoral and beach sediments, back-barrier deposits, fossil corals and other marine organisms that indicate past water levels. Others include a range of water levels: for example, corals grow up to mean low water mark and may show variability up to a $5 \mathrm{~m}$ water depth and with the rising sea-level some reefs are "keep up" (Barbados), "catch up" (Bermuda) or "give up" (Neumann

Published by Copernicus Publications on behalf of the European Geosciences Union. 
and MacIntyre, 1985). The most reliable indicators of former sea-levels are shoreline angles, notches and back barrier deposits and are used in this analysis.

Estimates of the MIS 11 sea-level relative to present sealevel fall into two groups. First: below present sea-level to $\sim 6 \mathrm{~m}$ above it (Bender et al., 1979; Suggate, 1992; McManus et al., 1999; Vézina et al., 1999; Murray-Wallace, 2002; Bowen, 2003a; Schellmann and Radtke, 2004a, b; Thompson and Goldstein, 2005). Second: a higher group at $\sim 20 \mathrm{~m}$ a.s.l. (Pirrazoli et al., 1993; Howard, 1997; Hearty, 2002; Hearty et al., 1999; Olson and Hearty, 2009; Rohling et al., 1998). These compare with inferences of sea-level from $\delta^{18} \mathrm{O}$ of a band of sea-levels between $\sim 0 \mathrm{~m}$ (McManus et al., 1999, 2003) and $\sim 6 \mathrm{~m}$ (Waelbroeck, 2002).

\section{Method}

Estimating MIS 11 sea-levels is based on an "uplift correction" procedure that calculates average (not constant) tectonic rates of uplift from uplifted and dated MIS 5.5 shorelines (Chappell, 1974). Such average uplift rates may then be extrapolated to dated MIS 11 shorelines. The "uplift correction" formula is based on Pillans et al. (1998):

$S=H-U t, \quad$ with $\quad U=\left(H^{*}-S^{*}\right) / t^{*}$

where $S$ is sea-level at time $t$ relative to present sea-level, $H$ is the elevation of the marine deposit with age $t$, and where $U$ is the average tectonic uplift rate at a location. $U$ is calculated from the elevation $H^{*}$ of a reference marine deposit of age $t^{*}$. $H$ and $H^{*}$ should ideally lie on, or close to, a transect normal to the present shoreline.

Relatively few age estimates are available for uplifted MIS 11 shorelines. Some locations have age estimates based on U-series, ESR, AAR and TL in certain environments (see Sect. 3.2). Time $t$, however, is taken as event MIS 11.3 (406 ka) on the Bassinot et al. (1994) timescale. It receives strong support from the ${ }^{40} \mathrm{Ar} /{ }^{39} \mathrm{Ar}$ ages of $416 \pm 11$ and $407 \pm 11$ on tephra within estuarine sediments in Lazio downstream from Rome (Karner and Marra, 2003). Time $t^{*}$ (MIS 5.5) is used to calculate uplift rates for "uplift correction". But unfortunately there is no universal agreement on its precise age or the elevation of its sea-level, and ages range from $\sim 132$ to $116 \mathrm{ka}$. These point to a longer interglacial than predicted by orbital theory (Muhs, 2002; Muhs and Szabo, 1994; Muhs et al., 2002; Stein et al., 1993). Thus, the global complexity of the climate system may have resulted in a long sea-level response during the last interglacial (Muhs et al., 2002), with different responses in earlier ones (Siddall et al., 2007). During the possible $\sim 16 \mathrm{kyrs}$ of the last interglacial (MIS 5.5) some variability in sea-level occurred as, on one hand, inferred from $\delta^{18} \mathrm{O}$ at site ODP 980 west of Ireland (McManus et al., 1999; Oppo et al., 2006), and on the other hand from detailed geomorphological mapping and ESR ages on reefs and terraces in Barbados (Schellmann

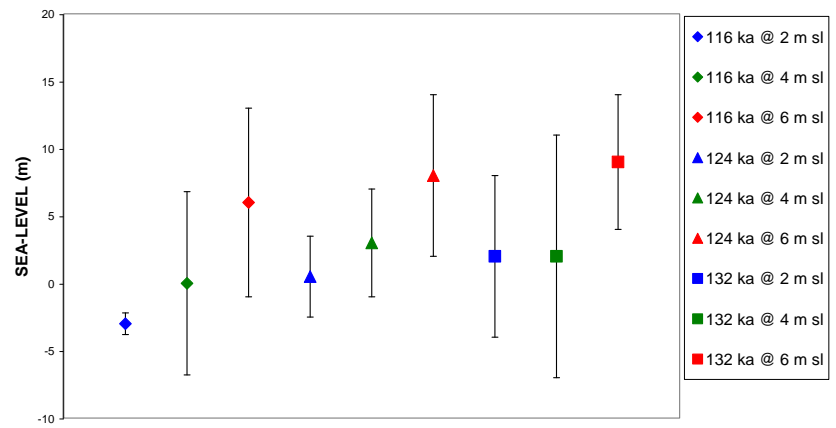

Fig. 1. MIS 11.3 sea-level and MIS 5.5 sea-level estimates for average uplift rates.

and Radtke, 2004a, b). It has been suggested that the highest MIS 5.5 sea-level occurred late and precipitously and was caused by a catastrophic collapse of the West Antarctic icesheet (Hollin, 1965; Neumann and Hearty, 1996; Hearty et al., 2007), but this has received little support (Carew, 1997; Mylroie, 1997).

The elevation of the last interglacial MIS 5.5 sea level $\left(H^{*}\right)$ has been generally accepted as $6 \mathrm{~m}$ a.s.l. But a review of the literature by Murray-Wallace and Belperio (1991) concluded that: "the concept of a reference level of $6 \mathrm{~m}$ for the elevation of the MIS 5.5 sea-level is based on the observations of Veeh (1960) that fossil corals throughout the Pacific and Indian Oceans are found consistently between $2 \mathrm{~m}$ and $9 \mathrm{~m}$. Broecker et al. (1968), Chappell (1974), Bloom et al. (1974) and many others have since used a $6 \mathrm{~m}$ reference as a de facto global eustatic sea-level for the last interglaciation". It was proposed that the coastline of the stable Gawler craton in South Australia was a better MIS 5.5 sea-level datum because its shoreline runs for $\sim 150 \mathrm{~km}$ at an elevation of $2 \mathrm{~m}$ (Murray-Wallace and Belperio, 1991). Similarly, a stable area of West Australia was proposed as an informal type area for the MIS 5.5 sea-level where TIMS ages of $128 \pm 1$ to $116 \pm 1$ on corals lie at about $3 \mathrm{~m}$ a.s.l. (Stirling et al., 1998). Since the review of Murray-Wallace and Belperio (1991) other locations have been discovered with an MIS 5.5 sea-level of $6 \mathrm{~m}$. But all require evaluation of their tectonic history, and it seems unlikely that tectonic stability can be taken for granted anywhere.

Because of the range of ages and sea-level elevations for the MIS 5.5 sea-level in the literature, different ages and sealevels are used to explore possible uplift rates and estimates of the MIS 11 sea-level (Tables 2, 3 and Fig. 1). Calculations based on the uplift rate of the MIS 5.5 sea-level at different locations (Table 1) are made with sea-level at $2 \mathrm{~m}, 4 \mathrm{~m}$ and $6 \mathrm{~m}$ for ages of $116 \mathrm{ka}, 124 \mathrm{ka}$ and $132 \mathrm{ka}$, which represent the earliest, latest, and median ages of MIS 5.5. Table 3 shows the results from which outliers, defined at, or greater than, two standard deviations, have been removed (Tables 2 and 3). 
Table 1. Locations arranged in order of increasing uplift (example is MIS 5.5 sea-level of $2 \mathrm{~m}$ at $124 \mathrm{ka}$ ), evidence for MIS 5.5 and MIS 11 shorelines and tectonic style of locations.

\begin{tabular}{lllll}
\hline Location & $\begin{array}{l}\text { Uplift } \\
\mathrm{m} / \mathrm{ka}\end{array}$ & MIS 5.5 & MIS 11 & Tectonic \\
\hline Charleston S Carolina & 0.05 & back-barrier & back-barrier & Carolina Platform \\
Coorong CP Aust. & 0.07 & back-barrier & back-barrier & intra plate \\
Curacao, Antilles & 0.07 & coral platform & coral platform & island arc \\
Nome, Alaska & 0.08 & shoreline & shoreline & intra plate \\
Lazio, Italy & 0.15 & shoreline angle & estuarine & Extensional belt \\
Barbados & 0.3 & shoreline angle & shoreline angle & island arc \\
Sumba I, Indonesia & 0.47 & shoreline angle & shoreline angle & island arc \\
\hline
\end{tabular}

Table 2. MIS 11 sea-levels $(S)$ calculated from different MIS 5.5 Ages and sea-levels for uplift correction (Table 3). Sea-level Calculations with removal of outliers (blank spaces) identified at or greater than two standard deviations. Numbers rounded-up.

\begin{tabular}{lrrrrrrrrrr}
\hline Age ka & \multicolumn{1}{c}{116} & \multicolumn{1}{c}{124} & \multicolumn{1}{c}{132} & $S$ \\
\cline { 2 - 9 } MIS 5.5 s-1 & 2 & 4 & 6 & 2 & 4 & 6 & 2 & 4 & 6 & \\
\hline Charleston & -5 & 3 & 7 & -5 & 3 & 7 & -5 & 3 & 7 & $2 \pm 5$ \\
Coorong CP & -2 & 6 & 14 & 0 & 6 & 14 & 2 & 6 & 14 & $7 \pm 6$ \\
Curacao & -3 & 5 & 13 & 3 & 5 & 13 & 1 & 9 & 13 & $7 \pm 6$ \\
Nome CP & & -5 & 3 & & -1 & 3 & -9 & -1 & 3 & $-1 \pm 5$ \\
Lazio & -2 & 6 & & 2 & & & 6 & & & $3 \pm 4$ \\
Barbados & -2 & -2 & -2 & -2 & -2 & -2 & 6 & 10 & & $0.5 \pm 5$ \\
Sumba I & -13 & -13 & -1 & -1 & 7 & 11 & 11 & -13 & & $-1.5 \pm 11$ \\
\hline$S$ & -3 & 0 & 6 & 0.5 & 3 & 8 & 2 & 2 & 9 & \\
& \pm 1 & \pm 7 & \pm 7 & \pm 3 & \pm 4 & \pm 6 & \pm 6 & \pm 9 & \pm 5 & \\
\hline
\end{tabular}

Viscoelastic Earth models have investigated glacio-hydroisostatic processes that caused spatial and temporal variability in sea-level for Termination 1 at the MIS $2 / 1$ transition (e.g. Peltier, 2004), and Termination 2 at the MIS 6/5.5 transition (Lambeck and Nakada, 1992; Potter and Lambeck, 2003). These models, however, require verification from field geology and a powerful argument against the glaciohydro-isostatic model for T2 is the observation that MIS 5.5 marine deposits on apparently stable intermediate-field localities such as The Bahamas, Bermuda, California and Baja California are: "not significantly higher than those of MIS 5.5 age in far-field apparently stable localities such as Western Australia" (Muhs et al., 2002). It may indicate that glacio-hydro-isostatic recovery is rapid and that it is not yet possible to model the T2 event. Potter and Lambeck (2003) have also suggested that MIS 5.1 marine deposits above sea-level on the US Atlantic Coastal Plain (Wehmiller et al., 2008) result from glacio-hydro-isostasy. Yet Muhs et al. (2002) suggest that such a high sea-level should be expected, given the complete deglaciation of the Laurentide Ice Sheet at a time when Baffin Island was warmer than the Holocene (Miller et al., 1999; Wolfe et al., 2000). Summer temperatures, higher than present, in northern Fennoscandia during MIS 5.1 also suggest complete deglaciation of the Fennoscandian ice sheet (Valiranta et al., 2009). Thus, not only could the MIS 5.1 sea-level have been close to present, its effect on soft sediment coasts may have been significant and account for the MIS 5.1 sea-level at Gomez Pit, Virginia (Mirecki et al., 1995; Wehmiller et al., 2008). It is unlikely that the effects of glacio-hydro-isostasy on sea-level variability can be discovered for MIS 12/11(Termination V).

\section{Location}

\subsection{Charleston, South Carolina, USA}

The Atlantic Coastal Plain between the Fall Line and the edge of the Continental Shelf is the inner edge of a passive continental margin and its marine sediments range from Miocene to Holocene (Cronin, 1981). Their study has been characterised by two approaches; one geomorphological the other palaeontological. While the former recognised gently inclined marine terraces with shoreline features, it became evident that the terraces do not correspond to 
Table 3. Estimates of the MIS 11 (406 ka) sea-level from assumptions of uplift rates using different ages and sea-levels for MIS 5.5 (see Method). Numbers in bold type are excluded because they lie at or are greater than two standard deviations. All numbers are rounded up.

\begin{tabular}{|c|c|c|c|c|c|c|}
\hline $116 \mathrm{ka} 2 \mathrm{~m}$ & $H$ & $H^{*}$ & $H^{*}-2$ & uplift m/ka & UC & $S$ \\
\hline Charleston & 15 & 8 & 6 & 0.05 & 20 & -5 \\
\hline Coorong CP & 26 & 10 & 8 & 0.07 & 28 & -2 \\
\hline Curacao & 29 & 11 & 9 & 0.08 & 32 & -3 \\
\hline Nome CP & 23 & 12 & 10 & 0.09 & 37 & -14 \\
\hline Rome CP & 63 & 20 & 18 & 0.16 & 65 & -2 \\
\hline Barbados & 120 & 39 & 37 & 0.3 & 130 & -2 \\
\hline \multirow[t]{2}{*}{ Sumba I } & 190 & 60 & 58 & 0.5 & 203 & -13 \\
\hline & & & & & $\begin{array}{c}\text { MEAN } \\
\pm\end{array}$ & $\begin{array}{r}-3 \\
1\end{array}$ \\
\hline $116 \mathrm{ka} 4 \mathrm{~m}$ & $H$ & $H^{*}$ & $H^{*}-4$ & uplift m/ka & UC & $S$ \\
\hline Charleston & 15 & 8 & 4 & 0.03 & 12 & 3 \\
\hline Coorong CP & 26 & 10 & 6 & 0.05 & 20 & 6 \\
\hline Curacao & 29 & 11 & 7 & 0.06 & 24 & 5 \\
\hline Nome CP & 23 & 12 & 8 & 0.07 & 28 & -5 \\
\hline Rome CP & 63 & 20 & 16 & 0.14 & 57 & 6 \\
\hline Barbados & 120 & 39 & 35 & 0.3 & 122 & -2 \\
\hline \multirow[t]{2}{*}{ Sumba I } & 190 & 60 & 56 & 0.5 & 203 & -13 \\
\hline & & & & & $\begin{array}{c}\text { MEAN } \\
\pm\end{array}$ & $\begin{array}{l}0 \\
7\end{array}$ \\
\hline $116 \mathrm{ka} 6 \mathrm{~m}$ & $H$ & $H^{*}$ & $H^{*}-6$ & uplift m/ka & $\mathrm{UC}$ & $S$ \\
\hline Charleston & 15 & 8 & 2 & 0.02 & 8 & 7 \\
\hline Coorong CP & 26 & 10 & 4 & 0.03 & 12 & 14 \\
\hline Curacao & 29 & 11 & 5 & 0.04 & 16 & 13 \\
\hline Nome CP & 23 & 12 & 6 & 0.05 & 20 & 3 \\
\hline Rome CP & 63 & 20 & 14 & 0.12 & 49 & 22 \\
\hline Barbados & 120 & 39 & 33 & 0.3 & 122 & -2 \\
\hline \multirow[t]{2}{*}{ Sumba I } & 190 & 60 & 54 & 0.47 & 191 & -1 \\
\hline & & & & & $\begin{array}{c}\text { MEAN } \\
\pm\end{array}$ & $\begin{array}{l}6 \\
7\end{array}$ \\
\hline $124 \mathrm{ka} 2 \mathrm{~m}$ & $H$ & $H^{*}$ & $H^{*}-2$ & uplift $\mathrm{m} / \mathrm{ka}$ & $\mathrm{UC}$ & $S$ \\
\hline Charleston & 15 & 8 & 6 & 0.05 & 20 & -5 \\
\hline Coorong CP & 26 & 10 & 8 & 0.07 & 26 & 0 \\
\hline Curacao & 29 & 11 & 9 & 0.07 & 26 & 3 \\
\hline Nome CP & 23 & 12 & 10 & 0.08 & 33 & -9 \\
\hline Rome CP & 63 & 20 & 18 & 0.15 & 59 & 2 \\
\hline Barbados & 120 & 39 & 37 & 0.3 & 122 & -2 \\
\hline \multirow[t]{2}{*}{ Sumba I } & 190 & 60 & 58 & 0.47 & 190 & -1 \\
\hline & & & & & $\begin{array}{c}\text { MEAN } \\
\pm\end{array}$ & $\begin{array}{r}0.5 \\
3\end{array}$ \\
\hline $124 \mathrm{ka} 4 \mathrm{~m}$ & $H$ & $H^{*}$ & $H^{*}-4$ & uplift m/ka & UC & $S$ \\
\hline Charleston & 15 & 8 & 4 & 0.03 & 12 & 3 \\
\hline Coorong CP & 26 & 10 & 6 & 0.05 & 20 & 6 \\
\hline Curacao & 29 & 11 & 7 & 0.06 & 24 & 5 \\
\hline Nome CP & 23 & 12 & 8 & 0.06 & 24 & -1 \\
\hline Rome CP & 63 & 20 & 16 & 0.13 & 53 & 10 \\
\hline Barbados & 120 & 39 & 35 & 0.3 & 122 & -2 \\
\hline \multirow[t]{2}{*}{ Sumba I } & 190 & 60 & 56 & 0.45 & 183 & 7 \\
\hline & & & & & $\begin{array}{c}\text { MEAN } \\
\pm\end{array}$ & $\begin{array}{l}3 \\
4\end{array}$ \\
\hline
\end{tabular}

Table 3. Continued.

\begin{tabular}{|c|c|c|c|c|c|c|}
\hline $124 \mathrm{ka} 6 \mathrm{~m}$ & $H$ & $H^{*}$ & $H^{*}-6$ & uplift $\mathrm{m} / \mathrm{ka}$ & UC & $S$ \\
\hline Charleston & 15 & 8 & 2 & 0.02 & 8 & 7 \\
\hline Coorong CP & 26 & 10 & 4 & 0.03 & 12 & 14 \\
\hline Curacao & 29 & 11 & 5 & 0.04 & 16 & 13 \\
\hline Nome CP & 23 & 12 & 6 & 0.05 & 20 & 3 \\
\hline Rome CP & 63 & 20 & 14 & 0.1 & 41 & 22 \\
\hline Barbados & 120 & 39 & 33 & 0.3 & 122 & -2 \\
\hline \multirow[t]{2}{*}{ Sumba I } & 190 & 60 & 54 & 0.44 & 179 & 11 \\
\hline & & & & & $\begin{array}{c}\text { MEAN } \\
\pm\end{array}$ & $\begin{array}{l}8 \\
6\end{array}$ \\
\hline $132 \mathrm{ka} 2 \mathrm{~m}$ & $H$ & $H^{*}$ & $H^{*}-2$ & uplift m/ka & $\mathrm{UC}$ & $S$ \\
\hline Charleston & 15 & 8 & 6 & 0.05 & 20 & -5 \\
\hline Coorong CP & 26 & 10 & 8 & 0.06 & 24 & 2 \\
\hline Curacao & 29 & 11 & 9 & 0.07 & 28 & 1 \\
\hline Nome CP & 23 & 12 & 10 & 0.08 & 32 & -9 \\
\hline Rome CP & 63 & 20 & 18 & 0.14 & 57 & 6 \\
\hline Barbados & 120 & 39 & 37 & 0.28 & 114 & 6 \\
\hline \multirow[t]{2}{*}{ Sumba I } & 190 & 60 & 58 & 0.44 & 179 & 11 \\
\hline & & & & & $\begin{array}{c}\text { MEAN } \\
\pm\end{array}$ & $\begin{array}{l}2 \\
6\end{array}$ \\
\hline $132 \mathrm{ka} 4 \mathrm{~m}$ & $H$ & $H^{*}$ & $H^{*}-4$ & uplift $\mathrm{m} / \mathrm{ka}$ & $\mathrm{UC}$ & $S$ \\
\hline Charleston & 15 & 8 & 4 & 0.03 & 12 & 3 \\
\hline Coorong CP & 26 & 10 & 6 & 0.05 & 20 & 6 \\
\hline Curacao & 29 & 11 & 7 & 0.05 & 20 & 9 \\
\hline Nome CP & 23 & 12 & 8 & 0.06 & 24 & -1 \\
\hline Rome CP & 63 & 20 & 16 & 0.1 & 41 & 22 \\
\hline Barbados & 120 & 39 & 35 & 0.27 & 110 & 10 \\
\hline \multirow[t]{3}{*}{ Sumba I } & 190 & 60 & 56 & 0.5 & 203 & -13 \\
\hline & & & & & MEAN & 2 \\
\hline & & & & & \pm & 8.5 \\
\hline $132 \mathrm{ka} 6 \mathrm{~m}$ & $H$ & $H^{*}$ & $H^{*}-6$ & uplift $\mathrm{m} / \mathrm{ka}$ & UC & $S$ \\
\hline Charleston & 15 & 8 & 2 & 0.02 & 8 & 7 \\
\hline Coorong $\mathrm{CP}$ & 26 & 10 & 4 & 0.03 & 12 & 14 \\
\hline Curacao & 29 & 11 & 5 & 0.04 & 16 & 13 \\
\hline Nome CP & 23 & 12 & 6 & 0.05 & 20 & 3 \\
\hline Rome CP & 63 & 20 & 14 & 0.1 & 41 & 22 \\
\hline Barbados & 120 & 39 & 33 & 0.25 & 101 & 18 \\
\hline \multirow[t]{2}{*}{ Sumba I } & 190 & 60 & 54 & 0.4 & 162 & 28 \\
\hline & & & & & $\begin{array}{c}\text { MEAN } \\
\pm\end{array}$ & $\begin{array}{l}9 \\
5\end{array}$ \\
\hline
\end{tabular}

lithostratigraphical units although both were combined by Colquhoun (1965; Colquhoun et al., 1991). Six Quaternary marine lithostratigraphical units run north-east broadly in parallel with the modern shoreline (McCartan et al., 1984; McCartan, 1988). In each one, several lithofacies tend to grade into each other and consist of burrowed, fine to medium-grained sand with interbedded mud and shells, wellsorted fine to medium-grained sand and back-barrier muddy fine to medium-grained sand, mud and shells, as well as fluvial lithofacies. In comparison with modern and Holocene (Unit Q1) deposits, McCartan (1988) believed that "The highest back-barrier deposits mark approximately the highest 
relative sea-level for each period of deposition". Backbarrier deposits up to $8 \mathrm{~m}$ occur in Unit Q2 (Wando Formation) and its late Pleistocene (MIS 5.5) age is based on Useries alpha ages on corals between 90 and $120 \mathrm{ka}$ (McCartan et al., 1980; Szabo, 1985), amino acid ratios (McCartan et al., 1982), as well as relatively fresh minerals (McCartan et al., 1982). The Ladson Formation (Unit Q4) of Malde (1959) has back-barrier deposits up to $15 \mathrm{~m}$. It is correlated with the Canepatch Formation at Myrtle Beach (SC) by a U-series alpha age of $\sim 450 \mathrm{ka}$ and by mollusc and ostracode faunas (Cronin in McCartan, 1988). The occurrence of the coccolith Gephyrocapsa supports an age ascribed to MIS 11 (Cronin et al., 1984). Uplift rates calculated from event MIS 5.5 back-barrier deposits do not differ greatly from those of Cronin (1981) who used shoreline datums related to lithospheric flexure of the Coastal Plain-offshore Carolina platform and Carolina Trough. Tables 2 and 3 show estimates of the MIS 11 sea-level.

\subsection{The Coorong Coastal Plain (SE South Australia)}

A spectacular sequence of uplifted Plio-Pleistocene barrier dunes and back-barrier deposits runs inland across the Coorong Coastal Plain (Murray-Wallace, 2002). Backbarrier lagoon and estuarine deposits are preserved in interdune corridors and consists largely of unsorted litho-facies with gastropods and articulated bivalves. Along a transect from Robe to Naracoorte, the Woakwine deposits at $10 \mathrm{~m}$ have a TL age of $132 \pm 9 \mathrm{ka}$, and the East Avenue deposits at $26 \mathrm{~m}$ have a TL age of $414 \pm 29$. Based on an uplift rate from an MIS 5.5 sea-level of $2 \mathrm{~m}$ the MIS 11 sea-level was calculated to be at $-3 \mathrm{~m}$ at $420 \mathrm{ka}$ (Murray Wallace, 2002). Tables 2 and 3 show estimates of the MIS 11 sea-level.

Some believe that the limit to TL dating is only about 100 kyrs. But much depends on the mineral used and the regional geology. In Australia, where dose rates are low, limits much greater than 100 kyrs may be expected (Berger, Huntley, Lancaster, personal communications, 2009), as in Spain, back to $\sim 1 \mathrm{Ma}$ (Berger et al., 2008) and Alaska back to $\sim 800 \mathrm{ka}$ (Berger et al., 1992). In the case of the Coorong Coastal Plain, there is a close correlation between TL and aminostratigraphical ages (Murray-Wallace, 2002). They are supplemented by some U-series and ESR ages on molluscs and corals (Murray-Wallace, 2002).

\subsection{Curacao (Netherlands Antilles)}

Curacao consists of off-lapping carbonate units forming marine terraces on a volcanic basement. Using TIMS ages Lundberg and McFarlane (2002) identified sea-levels of MIS 5.5 and MIS 11 events. The former has a well-preserved notch at $10.5 \mathrm{~m}$ with a TIMS age of $123.65 \pm 0.35 \mathrm{ka}$ on coral. A TIMS age on coral of $412 \pm 14 \mathrm{ka}$ dates "the base of the MIS 11 terrace" at $21 \mathrm{~m}$, whereas the notch above it is at $37 \mathrm{~m}$, so this may be older. The elevation used here is $29 \mathrm{~m}$ as mid-point between 37 and $21 \mathrm{~m}$. Tables 2 and 3 show estimates of the MIS 11 sea-level. If, however, the notch at $37 \mathrm{~m}$ is that of the MIS 11 sea-level, then six of the nine uplift correction calculations fail to meet the two standard deviations criterion. The remaining three give a sea-level estimate of $4 \pm 6$, but all nine provide an estimate of $10 \pm 12$.

\subsection{The Nome Coastal Plain, Alaska}

Six high stands of sea-level are found on the Nome Arctic Coastal Plain and consist of shorelines and superimposed shelf sequences with fossil evidence for climate that was as warm as, or warmer than, the present. Beaches, barrier islands and spits of the Pelukian marine transgression at $12 \mathrm{~m}$ (Brigham-Grette and Hopkins, 1995) are correlated with MIS 5.5 (Brigham-Grette, 1999). At $23 \mathrm{~m}$ a.s.l. lie shelf, beach and lagoonal sediments of the Karmuk Member of the Gubik Formation that is correlated with the Anvillian marine deposits of the Alaskan Coastal Plain (Kaufman, 1992; Kaufman and Brigham-Grette, 1993). They lie below glacial deposits of the Nome River Glaciation which is overlain by basaltic lava with ${ }^{40} \mathrm{Ar} /{ }^{39} \mathrm{Ar}$ age estimates of $470 \pm 190 \mathrm{ka}$ (Muhs et al., 2004). The Anvillian marine deposits are dated with AAR age estimates of about $475 \mathrm{ka}$. They have been correlated with the middle of the Rhizosolenia barboi diatom zone between 430 and $360 \mathrm{ka}$ (Pushgar et al., 1999). Tables 2 and 3 show estimates of the MIS 11 sealevel.

\subsection{San Paulo Formation, Lazio, Italy}

Downstream from Rome, fluviodeltaic sediments include the San Paulo Formation, silty sand with ostracodes, foraminifera as well as Cerastoderma and Tellina that indicate a brackish water environment (Karner and Marra, 1998). Its upper surface lies at $63 \mathrm{~m}$ (Karner and Marra, 1998; Karner and Renne, 1998; Karner and Marra, 2003). The formation includes tephra with ${ }^{40} \mathrm{Ar} /{ }^{39} \mathrm{Ar}$ ages of $416 \pm 11$ and $407 \pm 11$ (Karner and Marra, 2003). Downstream a marine terrace with a shoreline angle at $20 \mathrm{~m}$ is correlated with other sites in Lazio, notably Casale di Statua, that have definitive MIS 5.5 palaeontological and aminostratigraphical ages (Giordano et al., 2003; Ferranti et al., 2006). Tables 2 and 3 show estimates of the MIS 11 sea-level.

\subsection{Barbados}

Barbados has long been the testing ground for U-series ages on coral terraces (alpha and then TIMS ages from ${ }^{230} \mathrm{Th}$ and ${ }^{231} \mathrm{~Pa} /{ }^{235} \mathrm{Th}$ ) (Bender et al., 1979; Broecker et al., 1968; Mesolella et al., 1969; Edwards et al., 1997; Gallup et al., 2002). ESR ages on coral samples from sites determined by detailed geomorphological field mapping of former sea cliffs, erosional notches, reef crests, and wave cut terraces, at elevations surveyed to an accuracy of $1 \mathrm{~m}$, demonstrated 
18 separate stands of sea-level compared with only 11 previously recognised (Schellmann and Radtke, 2004a, b). The highest MIS 5.5 elevation (Terrace T-5b) is at $39 \mathrm{~m}$, with an ESR age of $132 \mathrm{ka}$. That of MIS 11 (Terrace T-13) is at $120 \mathrm{~m}$ with an ESR age of $410 \mathrm{ka}$ (Schellmann and Radtke, 2004a, b). Tables 2 and 3 show estimates of the MIS 11 sea-level.

\subsection{Sumba Island, Indonesia}

A flight of marine terraces at Cape Laundi on the northern side of Sumba Island Indonesia was mapped by Jouannic et al. (1988) (map in Bard et al., 1996), the oldest of which was correlated with MIS 27 (Pirazzoli et al., 1993). ESR ages on corals correlated with MIS 15 and MIS 9 showed an "uplift trend" of $0.49 \mathrm{~m} / \mathrm{ka}$ (Pirazzoli et al., 1993). Bard et al. (1996) used TIMS ages that identified the 5.1, 5.3, 5.5 (between 119 and $132 \mathrm{ka}$ ) and MIS 9 ( $\sim 305 \mathrm{ka})$, and suggested that the average uplift rate lies between 0.2 to $0.5 \mathrm{~m} / \mathrm{ka}$. The MIS 5.5 sea-level (reef complex II) lies at $60 \mathrm{~m}$ with TIMS ages close to $130 \mathrm{ka}$ (Bard et al., 1996). Reef terrace III 2 at $190 \mathrm{~m}$ has ESR ages of $322 \pm 48,327 \pm 49$ and $397 \pm 59 \mathrm{ka}$, and a ${ }^{230} \mathrm{Th}$ age of $>300 \mathrm{ka}$. It lies below terrace IV1 that has ESR ages of 584 \pm 88 and $609 \pm 90$ (Pirazzoli et al., 1993). Thus, terrace III2 is likely to mark the MIS 11 sea-level. Tables 2 and 3 show estimates of the MIS 11 sea-level.

\section{Discussion}

\subsection{MIS 11 sea-level at $1.5 \mathrm{~m} \pm 3$}

A range of possible sea-levels for MIS 11.3 from uplift correction calculations based on different assumptions for the MIS 5.5 sea-level and its age is presented in Fig. 1, Tables 2 and 3. The mean sea-level calculation for MIS 11.3 is $3 \pm 4 \mathrm{~m}$ $(n=9)$, but if outliers at two standard deviations or greater are removed the mean value is reduced to $1.5 \mathrm{~m} \pm 3(n=7)$. This is the same as the preferred calculation of Schellmann and Radtke (2004a, b) for the MIS 11 sea-level of $1.5 \mathrm{~m}$ (average of $5 \mathrm{~m}$ for Terrace T13 at $410 \mathrm{ka}$ and $-2 \mathrm{~m}$ sea-level for Terrace T12 at $398 \mathrm{ka}$ ) based on uplift correction using a $132 \mathrm{ka}$ MIS 5.5 aged sea-level at $2 \mathrm{~m}$. The Coorong Coastal Plain calculation of $-3 \mathrm{~m}$ sea-level at $420 \mathrm{ka}$ is also based on a $2 \mathrm{~m}$ sea-level for MIS 5.5 (Murray-Wallace, 2002). Because of their detailed geomorphology and geochronological age estimates Barbados and the Coorong Coastal Plain are arguably the most important locations under consideration. Both lie within the $1.5 \mathrm{~m} \pm 3$ band. Schellmann and Radtke (2004a, b) found that their Barbados estimates best fitted with the MIS 5.5 sea-level of $2 \mathrm{~m}$ from the Gawler Craton of MurrayWallace and Belperio (1991), and not with estimates based on an MIS 5.5 sea-level of $6 \mathrm{~m}$. Estimates of MIS 11 sealevels based on uplift correction from an MIS 5.5 sea-level at $6 \mathrm{~m}$ tend to lie on the higher side although none exceed $\sim 9 \mathrm{~m}$.

\subsection{High MIS sea-levels in Bermuda, Bahamas, Hawaii and Sussex (UK)}

Higher MIS 11 sea-levels $(\sim 20 \mathrm{~m})$ have been proposed in Bermuda (Hearty, 1998a, 2002; Hearty et al., 1999; Olson and Hearty, 2009), and have been widely adopted (e.g. Howard, 1997; Rohling et al., 1998; Droxler and Farrell, 2000). Similar high sea-levels have also been proposed in The Bahamas (Kindler and Hearty, 2000) and Oahu, Hawaii (Hearty, 2002).

In Bermuda, MIS 11 marine deposits have been described in karstic caves at Government Quarry. They occur at $18 \mathrm{~m}$ at Dead End Cave (Hearty et al., 1999) and $21 \mathrm{~m}$ at Calonectris Cave (Olson and Hearty, 2009; van Hengstum et al., 2009). At Government Quarry a wide range of TIMS ages $(127-680 \mathrm{ka})$ on "flowstone" in the succession of deposits are: $127 \pm 1.6 \mathrm{ka}, 420 \pm 30 \mathrm{ka}, 525 \pm 50 \mathrm{ka}$ and $680 \pm 130 \mathrm{ka}$ at the Dead End Cave (Hearty et al., 1999); 442 $\pm 123 \mathrm{ka}$, $503 \pm 110 \mathrm{ka}$ at Wilkinson Quarry (Olson and Hearty, 2009); and $125 \pm 4 \mathrm{ka}, 312 \pm 30 \mathrm{ka}, 360 \pm 40 \mathrm{ka}$ and $480 \pm 50 \mathrm{ka}$ at caves UGQ4 and UGQ5 (McMurty et al., 2007).

The Calonectris Cave deposits have, however, been attributed to a mega tsunami (McMurty et al., 2007) and other possibilities include tectonic uplift. Thus, if the highest MIS 5.5 marine deposits in Bermuda at $6 \mathrm{~m}$ (Harmon et al., 1983), with six TIMS ages between 125 and $113 \mathrm{ka}$ for the Rocky Bay Formation (MIS 5.5) (Muhs et al., 2002) are subject to uplift correction, the mean sea-level for any MIS 11 sealevels is $5 \pm 2 \mathrm{~m}$. Because the Fort St Catherine Formation (TIMS $\sim 80 \mathrm{ka}$ - Muhs et al., 2002) also lies above present sea-level, it may lend support to an uplift hypothesis (but see also Sect. 2 Method). Furthermore, at Rocky Bay (Land et al., 1967), the Belmont beach facies of MIS 7 is overlain unconformably by the Devonshire marine unit of the Rocky Bay Formation of MIS 5.5 age, which also points to uplift of the MIS 7 unit fashioned when sea-level was below present (Bard et al., 2002; Dutton et al., 2009). What, then, is so sacrosanct about the tectonic stability of Bermuda?

A further possibility is that of vertical transportation of fauna and sediments by hurricane winds. Subsequent entrainment and transport by fluvial means may have been followed by emplacement in phreatic cave systems, which were subsequently intersected by marine cliff retreat. The present position of the karstic caves at Government Quarry, up to $100 \mathrm{~m}$ from the Holocene shoreline because of quarrying, lends plausibility to this hypothesis. Hurricanes are wellknown for their wave generated effects and, for example, in 2004 Hurricane Ivan produced severe wave effects up to $27 \mathrm{~m}$ (Stone et al., 2005). During MIS 5.5 large boulders were emplaced some $20 \mathrm{~m}$ a.s.l. on Eluthera in the Bahamas (Hearty, 1998b).

Undated marine sediments at $18 \mathrm{~m}$ on Eluthera have been correlated with MIS 11 (Hearty, 1998a; Hearty et al., 1999). But they are interpreted as Holocene deposits emplaced during storm events by Mylroie (2008), who pointed out that 
the highest marine deposits on the island with TIMS ages of 131 to $119 \mathrm{ka}$ (Chen et al., 1991) lie no higher than $6 \mathrm{~m}$.

The Kaena marine deposits on Oahu, Hawaii, occur at $\sim 30 \mathrm{~m}$ (Stearns, 1966, 1978) and have been ascribed to MIS 11 (Hearty, 2002). This, however, is in conflict with TIMS ages of $532+130 /-70 \mathrm{ka}$ and $529+47 /-35 \mathrm{ka}$ that suggest the age of the Kaena sea-level event is 500-600 ka (Muhs et al., 2004).

The estimated MS 11 sea-level proposed in Sussex, England (Bowen, 1999) and cited by Olson and Hearty (2009) was withdrawn when it became clear that the stratigraphical geometry of complex sediments on the coastal plain, which included bivalves and gastropods with amino acid ratios correlated with MIS, 5.5, 7 and 9, did not provide a definitive elevation for the MIS 5.5 sea-level (Bowen, 2003a). But the aminostratigraphical correlation of the marine sands at Boxgrove with the MIS 11 marine clays (Hoxnian) in the Nar Valley, Cambridgeshire (Lewis, 1999) remains unchanged (Bowen, 2003b).

\subsection{Ice volume and sea-level}

Shackleton (1987) estimated that the MIS 12 sea-level was some $15 \%$ lower than that of the Last Glacial Maximum. Given an LGM sea-level of $-130 \mathrm{~m}$ (Clark and Mix, 2002) then on Shackleton's estimate the MIS 12 sea-level would have been $\sim-140 \mathrm{~m}$. This is supported by an estimate of $-140 \mathrm{~m}$ from a hydraulic model of water flow though the Strait of Bab-el-Mandab in the Red Sea (Rohling et al., 1998), notwithstanding a subsequent estimate based on inferences drawn from $\delta^{18} \mathrm{O}$ measurements (Rohling et al., 2009).

With an MIS 11 sea-level at $\sim 20 \mathrm{~m}$ then, the MIS 12/11 sea-level rise would have been $\sim 160 \mathrm{~m}$. This compares with only $130 \mathrm{~m}$ of sea-level rise at the MIS $2 / 1$ transition. Where did the extra $30 \mathrm{~m}$ of sea-level come from? What melted? Could it happen again (Chappell, 1998)? Hearty et al. (1999) suggested that the melting of Antarctic ice caused the MIS 11 high sea-level. Others (Rohling et al., 2009), however, estimated that a $20 \mathrm{~m}$ rise in sea-level would involve the melting of both West Antarctic and Greenland ice-sheets. Note, the Greenland ice sheet did not melt entirely during MIS 7 (Suwa et al., 2006) when sea-level was below present (Bard et al., 2002; Dutton et al., 2009), and the potential to raise present sea-levels with contributions of meltwater from the Greenland or Antarctic ice sheets is dominated by uncertainties (Alley et al., 2005).

An MIS 11 sea-level at or close to present does not require melting of the West Antarctic and Greenland ice sheets because only $140 \mathrm{~m}$ of sea-level rise is required. This is only $10 \mathrm{~m}$ more than the MIS 2/1 rise in sea-level, a volume readily accounted for by the melting of mid-latitude Northern Hemisphere ice sheets that were at their greatest extent of the last 0.5 Ma in MIS 12 (Sibrava et al., 1986; McManus et al., 1999).

\section{Conclusions}

Uplift correction, based on the assumptions stated at the outset, shows that the sea-level of MIS 11 at $406 \mathrm{ka}$ was closer to present than previously suggested.

An MIS 11 sea-level close to present is consistent with inferences drawn from benthic oxygen isotope stratigraphy (McManus et al., 2003) and lies within the band of sea-levels similarly estimated by Waelbroeck (2002).

Data from uplifted shorelines and inferences from benthic oxygen isotope stratigraphy suggest that both sea-level and global ice volume, though not necessarily its regional location, may have been broadly similar to those of the present during MIS 11.

This study of geological and geomorphological actualities in the field on the global shore at selected locations with age estimates for the MIS 11 shoreline, does not support an MIS 11 sea-level at $\sim 20 \mathrm{~m}$.

There is no need to invoke additional melting of the West Antarctic and Greenland ice sheets for the rise in sea-level from an MIS 12 low stand at $\sim-140 \mathrm{~m}$. The melting of Northern Hemisphere mid-latitude ice-sheets at their greatest extent during MIS 12 (Sibrava et al., 1986; McManus et al., 1999) yielded the greatest transfer of continental ice volume to the oceans of the last $0.5 \mathrm{Ma}$.

Orbital similarities between the MIS 11 and the present interglacial are the result of the $413 \mathrm{kyrs}$ Milankovitch pacing (Berger and Loutre, 2002). Compared with the duration of the present interglacial of $11.6 \mathrm{kyrs}$, MIS 11 lasted over $60 \mathrm{kyrs}$ and was the longest interglacial of the last $0.5 \mathrm{Ma}$ (Loutre and Berger, 2003). Given similar natural variability and configurations of continents, mountain ranges, seaways and orbitally controlled solar radiation, it is not unreasonable to suppose that in the "exceptionally long interglacial ahead" (Berger and Loutre, 2002) continental ice-volume and sealevel will also be similar to MIS 11: that is, subject to millennial and sub-millennial forcing.

Acknowledgements. I thank the Leverhulme Trust for an Emeritus Fellowship (2005-2007). John Mercer inspired me with his ideas on the relations between the last interglacial sea-level and the West Antarctic ice-sheet as we watched fireflies in his Columbus Ohio garden in 1969. Pat Suggate introduced me to the Westport, New Zealand, marine terraces during INQUA 1973, whence I returned in 1980; Brad Pillans introduced me to the shorelines of the Wanganui area North Island New Zealand in 1986; John Wehmiller and Ken Lajoie introduced me to the marine terraces between San Diego and Ventura in 1979 and Kathryn Hanson generously provided me with data and maps of the mid-California coast for field work in the 1990s. John Wehmiller and Tom Cronin took me to the Delmarva Peninsula and the Gomez Pit in Virginia. Len Vacher and John Wehmiller introduced me to Bermuda on the GSA Penrose meeting in Bermuda in 1977 - whence I later returned. Colin Murray-Wallace briefed me thoroughly before I visited the Coorong Coastal Plain. Thanks go to the referees: to Dan Muhs for his erudite review; and to John Mylroie for his support and additional information on The Bahamas. Jerry McManus 
steered this through editorially and I am glad to acknowledge his valued suggestions. I also thank C. Scott Howard of the South Carolina State Geological Survey who provided maps and monographs. Thanks also go to: Don Anderson, Glen Berger, Christina Gallup, Julie Brigham-Grette, David Huntley, Nick Lancaster, Jerry McManus, Chronis Tzedakis, Linda York, Steve Walsh and Ike Winograd for comments or help that brought this project to completion. Alun Rogers of Cardiff University assisted greatly in the preparation of the manuscript.

Edited by: J. McManus

\section{References}

Alley, R. B., Clark, P. U., Huybrechts, P., and Joughin, I.: Ice-Sheet and Sea-Level Changes, Science, 310, 456-460, 2005.

Bard, E., Jounnic, C., Hamelin, B., Pirazzoli, P., Arnold, M., Faure, G., and Sumosusastro, S.: Pleistocene sea-levels and tectonic uplift based on dating of corals from Sumba Island, Geophys. Res. Lett., 23, 1473-1476, 1996.

Bard, E., Antonioli, F., and Silenzi, S.: Sea-level during the antepenultimate interglacial period based on submerged stalagmite from Argentarola Cave, Earth Planet Sc. Lett., 196, 135-146, 2002.

Bassinot, F. C., Labeyrie, L. D., Vincent, E., Quidelleur, X., Shackleton, N. J., and Lancelot, Y.: The astronomical theory of climate and the age of the Brunhes-Matuyama magnetic reversal, Earth Planet Sc. Lett., 126, 91-108, 1994.

Bender, M. L., Fairbanks, R. G., Taylor, F. W., Matthews, R. K., Goddard, J. G., and Broecker, W. S.: Uranium-series dating of the reef tracts of Barbados, West Indies, Geol. Soc. Amer. Bull., 90, 577-594, 1979.

Berger, G. W., Pillans, B. J., and Palmer, A. S.: Dating loess up to $800 \mathrm{ka}$ by thermoluminescence, Geology, 20, 403-406, 1992.

Berger, G. W., Perez-Honza. E., Carbonell, E., Arsuaga, J. L., Bermua, J.-M., Castro, D., and Ku, T. L.: Luminescence chronology of cave sediments at the Atapuerca paleoanthropological site, Spain, J. Hum. Evol., 55, 300-311, 2008.

Berger, W. H. and Loutre, M. F.: An exceptionally long interglacial ahead, Science, 297, 1287-1288, 2002.

Bloom, A. L., Broecker, W. S., Chappell, J., Matthews, R. L., and Mesolella, K. J.: Quaternary sea-level fluctuations on a tectonic coast: New ${ }^{230} \mathrm{Th} /{ }^{238} \mathrm{U}$ U-series from Huon Peninsula, New Guinea, Quaternary Res., 4, 185-205, 1974.

Bowen, D. Q.: +23 m Sea Level in Southern Britain, in: Marine Oxygen Isotope Stage 11 and associated Terrestrial Records, edited by: Poore, R. Z., Burkle, L., Droxler, A., and McNulty, W. E., US Department of the Interior, US Geological Survey Open File Report, 99-312, 15-17, 1999.

Bowen, D. Q.: In search of the stage 11 sea level: traces on the global shore, XVI INQUA Congress, Reno, Nevada, 126, $2003 \mathrm{a}$.

Bowen, D. Q.: Uncertainty in oxygen isotope stage 11 sea-level: an estimate $13 \pm 2 \mathrm{~m}$ above low water from Great Britain, in: Earth's Climate and Orbital Eccentricity: The Marine Isotope Stage 11, edited by: Droxler, A., Poore, R. Z., and Burkle, L. H., Geophysical Monograph 137, American Geophysical Union, 131-144, 2003b.
Brigham, J. K.: Marine stratigraphy and amino acid geochronology of the Gubik Formation western Arctic Coastal Plain, Alaska, US Geological Survey Open-file report, 85-381, 1985.

Brigham-Grette, J. K.: Marine isotopic stage 11 high sea-level record from northwest Alaska, in: Marine Oxygen Isotope Stage 11 and associated Terrestrial Records, edited by: Poore, R. Z., Burkle, L., Droxler, A., and McNulty, W. E., US Department of the Interior Open-File Report, 99-312, 19-21, 1999.

Brigham-Grette, J. K. and Hopkins, D. M.: Emergent marine record and paleoclimate of the last interglaciation along the northwest Alaskan coast, Quaternary Res., 43, 154-173, 1995.

Broecker, W. S., Thurber, D. L., Goddard, J., Ku, T. L., Matthews, R. K., and Mesolella, K. J.: Milankovitch hypothesis supported supported by precise dating of coral reefs and deep sea sediments, Science, 159, 297-310, 1968.

Chappell, J.: Geology of coral terraces, Huon Peninsula, New Guinea: a study of Quaternary tectonic movements and sea-level changes, Geol. Soc. Am. Bull., 85, 553-570, 1974.

Chappell, J.: Jive talking, Nature, 394, 130-131, 1998.

Chen, J. H., Curran, H. A., White, B., and Wasserberg, G. J.: Precise geochronology of the last interglacial period: ${ }^{234} \mathrm{U}-{ }^{230} \mathrm{Th}$ data from fossil coral reefs in the Bahamas, Geol. Soc. Am. Bull., 103, 312-321, 1991.

Clark, P. U. and Mix, A. C.: Ice-sheets and sea level of the Last Glacial Maximum, Quaternary Sci. Rev., 21, 1-8, 2002.

Colquhoun, D. J.: Terrace sediment complexes in central south Carolina. Columbia, University of South Carolina, 1-62, 1965.

Colquhoun, D. J., Johnson, G. H., Peebles, P. C., Huddlestun, P. F., and Scott, T.: Quaternary geology of the Atlantic coastal plain, in: Quaternary nonglacial geology: Conterminous US, edited by: Morrison, R. B., The Geology of North American, K-2, Boulder, USA, 629-650, 1991.

Cronin, T. M.: Vertical crustal movements Atlantic Coastal Plain, Geol. Soc. Am. Bull., 92, 812-833, 1981.

Cronin, T. M., Szabo, B. J., Ager, T. A., Hazel, J. E., and Owens, J. P.: Quaternary climates and sea levels of the U.S. Atlantic coastal plain, Science, 211, 233-240, 1981.

Cronin, T. M., Bybell, L. M., Poore, R. Z., Blackwelder, B. W., Liddicoat, J. C., and Hazel, J. E.: Age and correlation of emerged Pliocene and Pleistocene deposits, U.S. Atlantic Coastal Plain, Palaeogeogr. Palaeocl., 47, 21-51, 1984.

Droxler, A. W. and Farrell, J. W.: Marine Isotope Stage 11 (MIS 11): New insights for a warmer future, Global Planet. Change, 24, 1-5, 2000 .

Dutton, A., Bard, E., Antonioli, F., Esat, T. M., Lambeck, K., and McCulloch, M. T.: Phasing and amplitude of sea-level and climate change during the penultimate interglacial, Nat. Geosci., 2, 355-359, 2009.

Emiliani, C.: Pleistocene temperatures, J. Geol., 63, 538-578, 1955.

Edwards, R. L., Cutler, K. B., Cheng, H., and Gallup, C. D.: Geochemical Evidence for Quaternary Sea-level Changes, Chapter 17, v.6, in: Treatise on Geochemistry, edited by: Holland, H. D., Turekian, K. K., and Elderfield, H., 6, 343-364, 2004.

Fairbridge, R. W.: Eustatic changes in sea-level, Phys. Chem. Earth, 4, 99-185, 1961.

Ferranti, L., Antonioli, F., Mauz, B., Amorosi, A., Dai Pra, G., Mastronuzzie, G., Monaco, C., Orrù, P., Pappalardoh, M., Radtke, U., Renda, P., Romano, P., Sansò, P., and Verrubbi, V.: Markers of the last interglacial sea-level high stand along the coast of Italy: 
Tectonic implications, Quatern. Int., 145-146, 30-54, 2006.

Gallup, C. D., Cheng, H., Taylor, F. W., and Edwards, R. L.: Direct Determination of the Timing of Sea Level Change During Termination II, Science, 295, 310-313, 2002.

Giordana, G., Esposito, A., De Rita, D., Fabbri, M., Mazzini, I., Trigari, A., Carlo Rosa, C., and Funiciello, R.: The sedimentation along the Roman Coast between Middle and Upper Pleistocene: the interplay of eustatism tectonics and volcanism, new data and review, Il Quaternario, 16, 115-121, 2003.

Harmon, R. S., Mitterer, R. M., Kriauskul, N., Land, L. S., Schwarz, H. P., Garrett, P., Larson, G. J., Vacher, H. L., and Rowe, M.: Useries and amino acid racemization geochronology of Bermuda: implications for eustatic sea-level over the past 250,000 years, Palaeogeogr. Palaeocl., 44, 41-70, 1983.

Hearty, P. J.: The geology of Eluthera Island, Bahamas: a Rosetta Stone of Quaternary stratigraphy and sea-level history, Quaternary Sci. Rev., 17, 333-355, 1998a.

Hearty, P. J.: Boulder deposits from large waves during the last interglaciation on north Eluthera island, Bahamas, Quaternary Res., 50, 309-322, 1998b.

Hearty, P. J.: The Kaèna highstand of Oàhu, Hawaii: further evidence of Antarctic ice collapse during the Middle Pleistocene, Pacific Science, 56, 65-81, 2002.

Hearty, P. J. and Kaufman, D. S.: Whole-Rock aminostratigraphy and Quaternary sea-level history of the Bahamas, Quaternary Res., 54, 163-173, 2000.

Hearty, P. J., Kindler, P., Cheng, H., and Edwards, R. L.: A +20 m middle Pleistocene sea-level highstand (Bermuda and the Bahamas) due to partial collapse of Antarctic ice, Geology, 27, 375378, 1999

Howard, W.: A warm future in the past, Nature, 388, 418-419, 1997.

Jouannic, C., Hantoro, W. S., Hoang, C. T., Fournier, M., Lafont, R., and Ichtam, M. L.: Quaternary raised reef terraces at cape Laundi, Sumba, Indonesia: geomorphological analysis and first radiometric $\mathrm{Th} / \mathrm{U}$ and ${ }^{14} \mathrm{C}$ age determinations, in: 6th Proceedings International coral reef symposium, edited by: Steneck, R. S., Choat, J. H., Barnes, D., and Borowitzka, M. A., Townsville, Australia, 2, 441-447, 1988.

Kindler, P. and Hearty, P. J.: Elevated marine terraces from Eluthera (Bahamas) and Bermuda: sedimentological, petrographic and geochronological evidence for important deglaciation events during the middle Pleistocene, Global Planet. Change, 24, 41-58, 2000.

Karner, D. B. and Marra, F.: Correlation of fluviodeltaic aggradationsal sections with glacial climate history: a revision of the Pleistocene stratigraphy of Rome, Geol. Soc. Am. Bull., 110, 748-758, 1998a.

Karner, D. B. and Marra, F.: ${ }^{40} \mathrm{Ar} /{ }^{39} \mathrm{Ar}$ dating of Glacial termination $\mathrm{V}$ and the duration of marine isotopic stage 11, in: Earth's Climate and Orbital Eccentricity: The Marine Isotope Stage 11, edited by: Droxler, A., Poore, R. Z., and Burkle, L. H., Geophysical Monograph 137, American Geophysical Union, 61-68, 2003.

Karner, D. H. and Renne, P. R.: ${ }^{40} \mathrm{Ar} /{ }^{39} \mathrm{Ar}$ geochronology of Roman volcanic province tephra in the Tiber river valley: age calibration of middle Pleistocene sea-level changes, Geol. Soc. Am. Bull., 110, 740-747, 1998.
Kaufman, D. S.: Aminostratigraphy of Pliocene-Pleistocene high sea-level deposits, Nome coastal plain and adjacent near shore are, Alaska, Geol. Soc. Am. Bull., 104, 40-52, 1992.

Kaufman, D. S. and Brigham-Grette, J. K.: Aminostratigraphic correlations and paleotemperature implications, PiocenePleistocene high sea-level deposits northwestern Alaska, Quaternary Sci. Rev., 12, 21-33, 1993.

Lambeck, K. and Nakada, M.: Constraints on the age and duration of the last interglacial period and on sea-level variations, Nature, 357, 125-128, 1992.

Land, L. S., Mackenzie, F. T., and Gould, S. J: The Pleistocene history of Bermuda, Geol. Soc. Am. Bull., 78, 993-1006, 1967.

Lea, D. W., Martin, P. A., Pak, D. K., and Spero, H. J.: Reconstructing a $350 \mathrm{ky}$ history of sea-level using planktonic $\mathrm{Mg} / \mathrm{Ca}$ and oxygen isotopic records from a Cocos Ridge core, Quaternary Sci. Rev., 21(1-3), 283-293, 2002.

Lewis, S. G.: Eastern England, in: A revised correlation of Quaternary deposits in the British Isles, edited by: Bowen, D. Q., Geol Soc. Lond., Spec. Rep., 23, 10-27, 1999.

Loutre, M. F. and Berger, A.: Marine isotope stage 11 as an analogue for the present interglacial, Global Planet. Change, 36, 209-217, 2003.

Lundberg, J. and McFarlane, D. A.: Isotope stage 11 sea-level in the Netherlands Antilles, Geological Society of America Programme with Abstracts 34, 6, 31, 2002.

Malde, H.: Geology of the Charleston phosphate area, South Carolina, US Geological Survey Bulletin, 1079, 1-105, 1959.

McCartan, L.: Studies related to the Charleston, South Carolina, Earthquake of 1886 - Neogene and Quaternary lithostratigraphy and biostratigraphy, US Geological Survey, 1367, A1-139, 1988.

McCartan, L., Weems, R. E., and Lemon Jr., E. M.: The Wando Formation (upper Pleistocene) in the Charleston, S.C. area, in Contributions to stratigraphy, US Geological Survey Bulletin, 1502A, A110-A116, 1980.

McCartan, L., Owens, J. P., Blackwelder, B. W., Szabo, B. J., Belknap, D. F., Kriausakul, N., Mitterer, R. M., and Wehmiller, J. F.: Comparison of amino acid racemization geochronometry, with lithostratigraphy, biostratigraphy, uranium-series coral dating and magnetostratigraphy in the Atlantic Coastal Plain of the southeastern United States, Quaternary Res., 18, 337-359, 1982.

McCartan, L., Lemon Jr., E. M, and Weems, R. E.: Geologic map of the area between Charleston and Orangeburg, South Carolina, US Geological Survey Map I-1472, 1984.

McManus, J. F., Oppo, D. W., and Cullen, J. L.: A 0.5-millionyear record of millennial-scale climate variability in the North Atlantic, Science, 283, 971-975, 1999.

McManus, J., Oppo, D., Cullen, J., and Healey, S.: Marine Isotope Stage 11 (MIS 11): analog for Holocene and future climate, in: Earth's Climate and Orbital Eccentricity: The Marine Isotope Stage 11, edited by: Droxler, A., Poore, R. Z., and Burkle, L. H., Geophysical Monograph 137, American Geophysical Union, 69-85, 2003.

McMurtry, G. M., Tappin, D. R., Sedwick, P. N., Wilkinson, I., Fietzke, J., and Sellwood, B.: Elevated marine deposits in Bermuda record a late Quaternary megatsunami, Sed. Geol., 200(3-4), 155-165, 2007.

Mesolella, K. J., Matthews, R. K., Broecker, W. S., and Thurber, D. L.: The astronomical theory of climatic change: data, J. Geol., 77, 250-274, 1969. 
Miller, G. H., Mode, W. N., Wolfe, A. P., Sauer, P. E., Bennike, O., Forman, S. L., Short, S. K., and Stafford Jr., T. W.: Stratified interglacial lacustrine sediments from Baffin Island, Arctic Canada: chronology and paleoenvironmental implications, Quaternary Sci. Rev., 18, 789-810, 1999.

Mirecki, J., Wehmiller, J. F., and Skinner, A. F.: Geochronology of Quaternary Coastal Plain deposits, Southeastern Virginia, USA, J. Coastal Res., 11, 1135-1144,1995.

Mix, A. C., Pisias, N. G., Rugh, W., Wilson, J., Morey, A., and Hagelberg, T. K.: Benthic foraminifera stable isotope record from SITE 849 (0-5 Ma): local and global climate changes, in: Proceedings ODP Scientific Results, edited by: Mayer, L. A., Janecek, T. R., Palmer-Julson, A., and van Andel, T. H., 138, 371-412, 1995.

Muhs, D. R.: Evidence for the timing and duration of the last interglacial period from high precision uranium series ages of corals on tectonically stable coastlines, Quaternary Res., 58, 36-40, 2002

Muhs, D. R., Simmons, K. R., Kennedy, G. L., and Rockwell, T. K.: The last interglacial period on the Pacific Coast of North America: timing and paleoclimate, Geol. Soc. Am. Bull., 114, 569-592, 2002.

Muhs, D. R. and Szabo, B. J.: New uranium-series ages of the Waimanalo Limestone, Oahu, Hawaii: implications for sea-level during the last interglacial period, Mar. Geol., 118, 315-326, 1994.

Muhs, D. R., Simmons, K. R., and Steinke, B.: Timing and warmth of the last interglacial period: new U-series evidence from Hawaii and Bermuda and a new fossil compilation for North America, Quaternary Sci. Rev., 21, 1355-1383, 2002.

Muhs, D. R., Rockwell, T. K., and Kennedy, G. L.: Late Quaternary uplift rates of marine terraces on the Pacific Coast of North America, Southern Oregon to Baja California Sur, Quatern. Int., 15-16, 121-133, 1992.

Muhs, D. R., Wehmiller, J. F., Simmons, K., and York, L. L.: Quaternary sea-level history of the United States, in: The Quaternary Period in the United States, edited by: Gillespie, A. R., Porter, S. C., and Atwater, B. F., Elsevier, Amsterdam, 147-184, 2004.

Murray-Wallace, C. V.: Pleistocene coastal stratigraphy, sea-level highstands and neotectonism of the southern Australian passive continental margin - a review, J. Quatern. Sci., 17, 469-489, 2002.

Murray-Wallace, C. V. and Belperio, A. P.: The last interglacial shoreline in Australia - a review, Quaternary Sci. Rev., 10, 441461, 1991.

Mylroie, J. E.: Late Quaternary sea-level position: Evidence from Bahamian carbonate deposition and dissolution cycles, Quatern. Int., 183, 61-75, 2008.

Neumann, A. C. and MacIntyre, I.: Reef response to sea-level rise: Keep-up, catch-up or give-up, Proceedings of the Fifth International Coral Reef Congress, 3, 105-110, 1985.

Olson, S. L. and Hearty, P. L.: A sustained $+21 \mathrm{~m}$ sea-level highstand during MIS 11 (400 ka): direct fossil and sedimentary evidence from Bermuda, Quaternary Sci. Rev., 28, 271-285, 2009.

Oppo, D. W., McManus, J. F., and Cullen, J. L.: Evolution and demise of the Last Interglacial warmth in the subpolar North Atlantic, Quaternary Sci. Rev., 25, 3268-3277, 2006.

Peltier, W. R.: Global glacial isostasy and the surface of the ice-age Earth, Annu. Rev. Earth Pl. Sc., 32, 111-149, 2004
Pillans, B., Chappell, J. W. C., and Naish, T. R.: A review of the Milankovitch climatic beat: template for Plio-Pleistocene sealevel changes and sequence stratigraphy, Sed. Geol., 122, 5-21, 1998.

Pirazzoli, P. A., Radtke, U., Hantoro, W. S., Jouannic, C., Hoang, C. T., Causse, C., and Borel Best, M.: A one-million-year-long sequence of marine terraces on Sumba Island, Indonesia, Mar. Geol., 109, 221-236, 1993.

Potter, E.-K. and Lambeck, K.: Reconciliation of sea-level observations in the western North Atlantic during the last glacial cycle, Earth Planet Sc. Lett., 217, 171-181, 2003.

Pushgar, V. S., Roof, S. R., Hopkins, D. M., and Brigham-Grette, J.: Paleogeographic and paleoclimatic significance of diatoms from Middle Pleistocene marine and glaciomarine deposits on Baldwin Peninsula, northwestern Alaska, Palaeogeogr. Palaeocl., 152, 67-85, 1999.

Rohling, E. J., Fenton, M., Jorissen, F. J., Bertrand, P., Ganssen, G., and Caulet, J. P.: Magnitudes of sea-level lowstands of the past 500,000 years, Nature, 394, 162-165, 1998.

Rohling, E. J., Grant, K., Bolshaw, M., Roberts, A. P., Siddall, M., Hemleben, Vh., and Kucera, M.: Antarctic temperature and global sea level closely coupled over the past five glacial cycles, Nat. Geosci., 2, 500-504, 2009.

Schellmann, G. and Radtke, U.: A revised morpho- and chronostratigraphy of the Late and Middle Pleistocene coral reef terraces on Southern Barbados (West Indies), Earth Science Reviews, 64, 157-187, 2004a.

Schellman, G. and Radtke, U.: The marine Quaternary of Barbados, Kölner Geographische Arbeiten, 81, 1-137, 2004b.

Shackleton, N. J.: The last interglacial in the marine and terrestrial record, Proceedings Royal Society of London, 215, 135154, 1967.

Shackleton, N. J.: Oxygen isotopes, ice volume and sea-level, Quaternary Sci. Rev., 6, 183-190, 1987.

Shackleton, N. J. and Opdyke, N. D.: Oxygen isotope and palaeomagnetic stratigraphy of Equatorial Pacific core V28-238: oxygen isotope temperatures and ice volumes on a $10^{5}$ year and $10^{6}$ year scale, Quaternary Res., 3, 39-55, 1973.

Shackleton, N. J. and Chappell, J.: Oxygen isotopes and sea level, Nature, 324, 137-140, 1986.

Sibrava, V., Bowen, D. Q., and Richmond, G. M.: Glaciations in the Northern Hemisphere, Quaternary Sci. Rev., 5, 1-511, 1986.

Siddall, M., Chappell, J., and Potter, E.-K.: Eustatic sea-level during past interglacials, in: The Climate of Past Interglacials, edited by: Sirocko, F., Claussen, M., Sánchez Goñi, M. F., and Litt, T., Elsevier, Amsterdam, 75-92, 2007.

Stearns, H. T.: Geology of the State of Hawaii, Pacific Books, Palo Alto, 1966.

Stearns, H. T.: Quaternary shorelines in the Hawaian Islands, Bernice P. Bish. Mus. B., 237, 1-57, 1978.

Stein, M., Wasserburg, G. J., Aharon, P., Chen, J. H., Zhu, Z. R., Bloom, A. L., and Chappell, J.: TIMS U-series dating and stable isotopes of the last interglacial event in Papua New Guinea, Geochim. Cosmochim. Ac., 57, 2541-2554, 1993.

Stirling, C. H., Esat, T. M., Lambeck, K., and McCulloch, M. T.: Timing and duration of the last interglacial: evidence for a restricted interval of widespread coral reef growth, Earth and Planetary Sciences, 160, 745-762, 1998. 
Stone, G. W., Walker, N. D., Hsu, S. A., Babin, A., Liu, B., Keim. B. D., Teague, W., Mitchell, D., and Leben, R.: Hurricane Ivan's Impact along the northern Gulf of Mexico, EOS T. Am. Geophys. Un. , 86(48), 497-501, 2005.

Suggate, P.: Differential uplift of middle and late Quaternary shorelines northwest South Island, New Zealand, Quatern. Int., 15-16, 47-59, 1992.

Suwa, M., von Fischer, J. C., and Bender, M. L.: Chronology reconstruction for the disturbed bottom section of the GISP2 and the GRIP ice cores: Implications for Termination II in Greenland, J. Geophys. Res., 111, D02101, doi:10.1029/2005JD006032, 2006.

Szabo, B. J.: Uranium-series dating of fossil corals from marine sediments of southeastern United States Atlantic coastal plain, Geol. Soc. Am. Bull, 96, 398-406, 1985.

Szabo, B. J., Ludwig, K. R., Muhs, D. R., and Simmons, K. R.: Thorium-230 ages of corals and duration of the last interglacial sea-level high stand on Oahu, Hawaiì, Science, 266, 93-96, 1994.

Thompson, W. G. and Goldstein, S. L.: Open-system coral ages reveal persistent suborbital sea-level cycles, Science, 308, 401404, 2005.

Väliranta, M., Birks, H. H., Helmens, K., Engels, S., and Piirainen, M: Early Weichselian interstadial (MIS 5c) summer temperatures were higher than today in northern Fennoscandia, Quaternary Sci. Rev., 28, 777-782, 2009.

van Hengstum, P. J., Scott, D. B., and Javaux, E. J.: Foraminifera in elevated Bermudian caves provide further evidence for $21 \mathrm{~m}$ eustatic sea level during Marine Isotope Stage 11, Quaternary Sci. Rev., 28(19-20), 1850-1869, 2009.
Veeh, H. H.: $\mathrm{Th}^{230} / \mathrm{U}^{238}$ and $\mathrm{U}^{234} / \mathrm{U}^{238}$ ages of Pleistocene high sea level stand, J. Geophys. Res., 71, 3379-3386, 1966.

Vézina, J., Jones, B., and Ford, D.: Sea-level highstands of the last 500,000 years; evidence from the Ironshore Formation on Grand Cayman, British West Indies, J. Sed. Res., 69, 317-327, 1999.

Waelbroeck, C., Laberyie, L., Michel, E., Duplessy, J. C., McManus, J. F., Lambeck, K., Balbon, E., and Labracherie, M.: Sea-level and deep water temperatures derived from benthic foraminifera isotopic records, Quaternary Sci. Rev., 21, 295306, 2002.

Wehmiller, J. F., Simmons, K. R., Cheng, H., Edwards, R. L., Martin-McNaughton, J., York, L. L., Krantz, D. E., and Shen, C.-C.: Uranium series coral ages from the US Atlantic Coastal Plain - the "80 ka problem" revisited, Quatern. Int., 120, 3-14, 2008.

Wolfe, A. P., Frechette, B., Richard, P. J. H., Miller, G. H., and Forman, S. L.: Paleoecology of a $>90,000$-year lacustrine sequence from Fog Lake, Baffin Island, Arctic Canada, Quaternary Sci. Rev., 19, 1677-1699, 1999.

Zeigler, K. E., Schwartz, J. P., Droxler, A. W., Shearer, M. C., and Peterson, L.: Caribbean carbonate crash in Pedro Channel at subthermoclinal depth during marine isotope stage 11: a case of basin to shelf carbonate fractionation?, in: Earth's Climate and Orbital Eccentricity: The Marine Isotope Stage 11, edited by: Droxler, A., Poore, R. Z., and Burkle, L. H., Geophysical Monograph 137, American Geophysical Union, 181-204, 2003. 